Grażyna B. Szczygiet

Uniwersytet $w$ Biatymstoku

\title{
POSTĘPOWANIE DYSCYPLINARNE W KODEKSIE KARNYM WYKONAWCZYM A EUROPEJSKIE REGUŁY WIĘZIENNE Z 2006 R.
}

W trakcie prac nad kodeksem karnym wykonawczym z 1997 r., jak podkreślono w uzasadnieniu projektu kodeksu ${ }^{1}$, kierowano się szeregiem międzynarodowych dokumentów. Wśród tych aktów - obok takich traktatów jak Europejska Konwencja o Ochronie Praw Człowieka i Podstawowych Wolności czy Międzynarodowy Pakt Praw Obywatelskich i Politycznych, które to akty Polska ratyfikowała - znalazły się Europejskie Reguły Więzienne, które nasze państwo, jako członek Rady Europy, zobowiązane jest stosować. W czasie prac nad kodeksem karnym wykonawczym były to Europejskie Reguły Więzienne z 1987 r. $^{2}$ Te Reguły w 2006 r. zastąpiono nową wersją Europejskich Reguł Więziennych ${ }^{3}$. Skłania to do spojrzenia na regulacje kodeksowe dotyczące postępowania ze skazanymi w izolacji penitencjarnej z perspektywy zaleceń zawartych w tym akcie. Zważywszy na szeroki zakres regulacji celowe jest dokonanie wyboru. Przedmiotem analizy uczyniono postępowanie dyscyplinarne.

Dlaczego ta problematyka? Postępowanie dyscyplinarne, które może prowadzić do ukarania skazanego, jawi się jako szczególnie ważkie w postępowaniu ze skazanymi w izolacji penitencjarnej. Kara pozbawienia wolności - jak żadna inna z kar - ingeruje w najcenniejsze po życiu dobro, jakim jest wolność. Mimo szerokiej ingerencji pozostawia, jak zauważa J. Śliwowski ${ }^{4}$, „swoisty margines wolności”. Następstwem postępowania dyscyplinarnego jest zawężenie „marginesu” tej jakże cennej

1 Uzasadnienie rządowego projektu nowego kodeksu karnego wykonawczego, (w:) Nowe kodeksy karne z 1997 roku z uzasadnieniami. Kodeks karny, Kodeks postępowania karnego, Kodeks karny wykonawczy, Warszawa 1997, s. 527.

$2 \quad$ Zalecenie $\mathrm{nr}$ R(87)3 Komitetu Ministrów dla państw członkowskich w sprawie Europejskich Reguł Więziennych przyjęte przez jej Komitet Ministrów dnia 12 lutego 1987 r. podczas 404. posiedzenia wiceministrów/zastępców ministrów. Tekst, (w:) D. Gajdus, B. Gronowska, Europejskie standardy traktowania więźniów (rekonstrukcja standardów i ich znaczenie dla polskiego prawa i praktyki penitencjarnej), Toruń 1998, s. 201-225.

3 Zalecenia Rec (2006)2 Komitetu Ministrów do państw członkowskich Rady Europy w sprawie Europejskich Reguł Więziennych przyjęte przez Komitet Ministrów w dniu 11 stycznia 2006 r. na 952. posiedzeniu delegatów. Tekst, (w:) Międzynarodowe standardy wykonywania kar, „Przegląd Więziennictwa Polskiego” 2011, nr 72-73, s. 33-69. J. Śliwowski, Prawo i polityka penitencjarna, Warszawa 1982, s. 189. 
dla skazanego wolności. Wymierzenie kary dyscyplinarnej skutkuje bowiem ograniczeniem - na pewien czas - korzystania przez skazanego z niektórych przysługujących mu praw (np. prawa do dokonywania zakupów artykułów żywnościowych, tytoniowych czy prawa do otrzymywania paczki żywnościowej) lub korzystania ze środków zindywidualizowanego oddziaływania (pozbawienie korzystania z udziału w niektórych zajęciach kulturalno-oświatowych czy sportowych).

Nie możemy jednak zapominać, że izolacja penitencjarna to życie w pewnej społecznej zbiorowości, a w każdej zbiorowości jej członków obowiązują określone zasady i obowiązki, które mają na celu zapewnienie porządku i bezpieczeństwa. Niepodporządkowanie się zasadom, niewypełnienie obowiązków powoduje określone konsekwencje. Zakład karny to szczególna zbiorowość, gdyż znajdują się w nim sprawcy czynów o znacznym stopniu społecznej szkodliwości, sprawcy, co do których sąd uznał za celowe odizolowanie ich - na pewien czas - od społeczeństwa. Ustawodawca zaś zobowiązuje administrację zakładu karnego do zapewnienia bezpieczeństwa w zakładzie, jak również bezpieczeństwa społeczeństwa poprzez utrzymywanie dyscypliny i porządku (art. 73 k.k.w.). Temu służą zakazy i nakazy określone w kodeksie karnym wykonawczym i w innych aktach wydanych na jego podstawie. Skazany musi je respektować, a gdy tego nie czyni ponosi konsekwencje w postaci kary dyscyplinarnej.

Twórcy Europejskich Reguł Więziennych istotną wagę przywiązują do procedur dyscyplinarnych, o czym świadczy sformułowanie szeregu zaleceń. Należy zauważyć, że także Europejski Komitet do spraw Zapobiegania Torturom oraz Nieludzkiemu lub Poniżającemu Traktowaniu albo Karaniu, formułując standardy ${ }^{5}$ związane z traktowaniem osób pozbawionych wolności zwrócił uwagę na postępowanie dyscyplinarne, wskazując na istotne znaczenie opracowania jasnej procedury dyscyplinarnej i jej stosowania, zarówno dla skazanych, jak i personelu więziennego. W ocenie Komitetu szczególnie istotne jest prawo skazanego do wysłuchania go w sprawie zarzucanego mu czynu, a także prawo do odwołania się do wyższej instancji.

Katalog zaleceń otwiera zasada ultima ratio postępowania dyscyplinarnego. Twórcy Reguł zalecając stosowanie procedur dyscyplinarnych w ostateczności (reg. 56) nawiązali do jednej z podstawowych zasad Europejskich Reguł Więziennych z 2006 r., a mianowicie, iż „Ograniczenia nakładane na osoby pozbawione wolności nie mogą przekraczać niezbędnego minimum i muszą być proporcjonalne do uzasadnionego celu, dla którego zostały nałożone" (reg. 3). W rozwiązywaniu sporów pomiędzy więźniami i z więźniami sugerują, gdy jest to możliwe, stosowanie mechanizmów polubownych i mediacji. Zwrócenie uwagi na wykorzystanie instytucji restytucji i mediacji jawi się jako szczególnie istotne z perspektywy celu wykonywania kary pozbawienia wolności, a mianowicie oferty pomocy skaza- 
nemu w kształtowaniu społecznie pożądanych postaw, a w szczególności poczucia odpowiedzialności.

Przechodząc do regulacji kodeksowych rodzi się pytanie, czy nasz ustawodawca czyni zadość temu zaleceniu? W tym miejscu należy zaznaczyć, iż w Europejskich Regułach Więziennych z 1987 r. nie wyartykułowano tej zasady. Analiza przepisów kodeksu karnego wykonawczego pozwala jednak na wskazanie regulacji, które do niej nawiązują.

Postępowanie dyscyplinarne, jak podkreśla się w doktrynie ${ }^{6}$, opiera się na zasadzie oportunizmu. Kary dyscyplinarne, zgodnie z art. $144 \S 2$ k.k.w., wymierza dyrektor zakładu karnego, w którym skazany przebywa. Może to również uczynić osoba upoważniona przez dyrektora, lecz tylko w przypadku niektórych kar. Dyrektor lub osoba przez niego upoważniona działa z urzędu lub na pisemny wniosek przełożonego skazanego, a więc - zgodnie z art. $72 \S 2$ k.k.w. - funkcjonariusza lub pracownika zakładu karnego, w którym przebywa skazany, jak również osoby kierującej pracą lub innymi zajęciami skazanego. Ustawodawca, jak zauważył Sąd Najwyższy $^{7}$ inicjatywę co do ukarania skazanego pozostawia dyrektorowi zakładu lub upoważnionej przez niego osobie. Tak więc wydaje się, iż nie ma przeszkód, by nie wszczynać postępowania dyscyplinarnego, gdy zachowanie skazanego wyczerpuje znamiona przekroczenia, a skazany uznał swoją winę i występuje np. z inicjatywą naprawienia wyrządzonej szkody. W ocenie S. Lelentala ${ }^{8}$, nieprzeprowadzenie postępowania dyscyplinarnego „w sytuacji gdy okoliczności popełnienia przekroczenia nie budzą wątpliwości, a skazany wyraził zgodę na wymierzenie mu kary przez siebie zaproponowanej lub uzgodnionej”, mieści się w mechanizmach mediacji, które to zalecają Europejskie Reguły Więzienne.

W uzasadnieniu przywołanego wyroku Sąd Najwyższy podkreślił także, że przepis art. $144 \S 2$ k.k.w. nie formułuje normy obligującej przełożonego skazanego do sporządzenia wniosku o ukaranie mimo ujawnienia przekroczenia, a jedynie pozostawia mu inicjatywę. Nie jest to jednak - jak zaznaczono - przyzwolenie do dowolnego postępowania, albowiem przepisy Ustawy o Służbie Więziennej ${ }^{9}$ nakładają na funkcjonariuszy w rocie ślubowania powinność realizacji zadań Służby Więziennej. Jednym zaś z podstawowych zadań, jakie ustawodawca stawia przed funkcjonariuszami Służby Więziennej, jest zapewnienie porządku i bezpieczeństwa w zakładzie karnym. Zdaniem Sądu w zależności od oceny wagi stwierdzonego przekroczenia funkcjonariusz - przełożony może sporządzić wniosek o wymierze-

Z. Hołda, (w:) Z. Hołda, K. Postulski, Kodeks karny wykonawczy. Komentarz, Gdańsk 2005, s. 483; A. Kwieciński, Procedura wymiaru i wykonania kar dyscyplinarnych wobec skazanych na karę pozbawienia wolności. Część I (art. 1444 k.k.w. - art. 145 k.k.w.), (w:) Nowa kodyfikacja prawa karnego, T. Kalisz (red.), Wrocław 2013, t. XXIX, s. 208.

7 Zob. wyrok Sądu Najwyższego z dnia 16 grudnia 2011 r. (V KK 140/11), http://lex.online.wolerskluwer.pl/ WKPLOnline

8 S. Lelental, Kodeks karny wykonawczy. Komentarz (4. wyd.), Warszawa 2012, s. 623-624.

9 Ustawa z dnia 9 kwietnia 2010 r. o Służbie Więziennej, Dz.U. z 2010 r. Nr 79, poz. 523 z późn. zm. 
nie kary dyscyplinarnej albo poprzestać na złożeniu raportu o przekroczeniu osobie uprawnianej w zakładzie karnym do wymierzenia kary.

W kontekście omawianego zalecenia należy także wskazać na instytucję odstąpienia od wymierzenia kary dyscyplinarnej. Wprawdzie decyzję ustawodawca pozostawia w gestii dyrektora, lecz wskazuje, iż tę instytucję można zastosować w wypadkach uzasadnionych względami wychowawczymi. Z pewnością ten warunek można uznać za spełniony w sytuacji gdy skazany, który dokonał przekroczenia następnie naprawił wyrządzoną szkodę, czy przeprosił pokrzywdzonego funkcjonariusza lub skazanego. Takie zachowanie bowiem może świadczyć o zrozumieniu przez skazanego naganności swojego czynu. W ocenie doktryny ${ }^{10}$ instytucja odstąpienia od wymierzenia kary jest wyrazem zasady oportunizmu.

Kolejna z zasad, na którą wskazano zarówno w Europejskich Regułach Więziennych z 1987 r. (reg. 35), jak i w Regułach z 2006 r. (reg. 57.2), to zasada określoności przekroczeń i rodzaju kar za nie grożących. Zgodnie z Regułami w prawie krajowym należy określić „działanie lub zaniechanie więźnia, które stanowi naruszenie dyscyplinarne" i ,rodzaj i wysokość kar dyscyplinarnych, które mogą być nałożone". Ponadto w ocenie twórców Europejskich Reguł Więziennych z 2006 r. (reg. 57.1) jedynie zachowanie mogące zagrozić porządkowi, bezpieczeństwu instytucjonalnemu lub bezpieczeństwu osobistemu może być uznane za przekroczenie dyscyplinarne.

W kodeksie karnym wykonawczym mamy ogólną definicję przekroczenia. Zgodnie z art. $142 \S 1$ k.k.w. przekroczeniem jest zawinione naruszenie nakazów lub zakazów wynikających z ustawy, regulaminu lub innych przepisów wydanych na jej podstawie lub ustalonego w zakładzie karnym lub miejscu pracy porządku.

Autorki ${ }^{11}$ komentarza do Europejskich Reguł Więziennych z 1987 r. zwróciły uwagę, że nowy kodeks karny wykonawczy nie czyni zadość oczekiwaniom Reguł, gdyż nie określa „katalogu przekroczeń dyscyplinarnych i kar grożących za nie”. Podkreśliły, że na podstawie praktyki można, z dużą łatwością, ustalić katalog najbardziej typowych przekroczeń dyscyplinarnych wraz z przyporządkowaniem im odpowiedniej kary, pozostawiając dyrektorom zakładów karnych instrumenty pozwalające na indywidualizację wymiaru kary. To stanowisko rodziło pytanie, co z zachowaniami nietypowymi ${ }^{12}$.

Skatalogowanie przekroczeń nie jest takie proste, świadczy o tym chociażby dyskusja w okresie prac nad obowiązującym kodeksem karnym wykonawczym ${ }^{13}$

\footnotetext{
10 Z. Hołda, (w:) Z. Hołda, K. Postulski, Kodeks karny wykonawczy, op. cit., s. 489. Zob. K. Postulski, Komentarz do art. 146, Kodeks karny wykonawczy. Komentarz, Lex.

11 D. Gajdus, B. Gronowska, Europejskie standardy traktowania więźniów, op. cit., s. 142.

12 Zob. szerzej G.B. Szczygieł, Kara dyscyplinarna umieszczenia w celi izolacyjnej a standardy międzynarodowe, (w:) Aktualne problemy prawa karnego, kryminologii i penitencjarystyki. Księga ofiarowana Profesorowi Stefanowi Lelentalowi w 45. roku pracy naukowej i dydaktycznej, Łódź 2004, s. 256.

13 Uzasadnienie rządowego projektu nowego kodeksu karnego wykonawczego, op. cit., s. 558.
} 
a właściwie jej efekt, czyli nieskatalogowanie przekroczeń ${ }^{14}$. Należy zauważyć, iż ten problem nie pojawił się po raz pierwszy w czasie prac nad nowym kodeksem karnym wykonawczym. Już w okresie międzywojennym, w trakcie prac nad reformą więziennictwa, dostrzegano celowość ,wskazania administracji więzienia jaki rodzaj kary za jakie przewinienia może być względem więźnia stosowany i kiedy". Zdaniem Z. Bugajskiego ${ }^{15}$. „W czasie pobytu w więzieniu więzień podlega prawie wyłącznie jurysdykcji administracji więziennej i otóż częstokroć naczelnicy więzień nierozumiejąc znaczenia rozumnego wymiaru kary za jedynie skuteczny środek dyscyplinarny, uważają wyznaczenie w każdym nawet w błahym przypadku przewinienia kary najsurowszej”. W efekcie w regulaminie więziennym z 1931 r. podjęto się, jak zauważa J. Śliwowski ${ }^{16}$, wprowadzenia w pewnym stopniu zasady nullum delictum sine lege ${ }^{17}$. Patrząc na kolejne akty odnoszące się do problematyki wykonywania kary pozbawienia wolności tylko w Instrukcji w sprawie regulaminu więziennego wydanej w 1945 r. za określone przekroczenie wskazywano konkretną karę ${ }^{18}$. Katalogu przekroczeń nie umieszczono w kodeksie karnym wykonawczym z 1969 r., ${ }^{19}$ jak również w kolejnych regulaminach wykonywania kary pozbawienia wolności.

Oczywiście należy podzielić stanowisko, że ze względu na gwarancyjną funkcję prawa sformułowanie katalogu przekroczeń byłoby bez wątpienia celowe ${ }^{20}$. Niewątpliwie można przyjąć, jako punkt wyjścia, obowiązki skazanego i zakazy. Lecz już tu rodzi się problem. W art. 116 k.k.w. określono obowiązki, ale nie uczyniono tego szczegółowo. Wskazano, że obowiązkiem skazanego jest przestrzeganie przepisów określających zasady i tryb wykonywania kary pozbawienia wolności, przestrzeganie ustalonego w zakładzie karnym porządku oraz wykonywanie poleceń przełożonych i innych osób, a następnie wymieniono kilka obowiązków. Zważywszy, że wyliczenie obowiązków poprzedzono sformułowaniem „w szczególności”, a więc nie tworzą one katalogu zamkniętego. Nawet gdy uwzględnimy wymienione w art. 116 a k.k.w. zakazy, które tworzą katalog zamknięty, to jednak nie skatalogujemy

14 W kodeksie karnym wykonawczym wskazano jeden typ przekroczenia, a mianowicie samouszkodzenie pociągające odpowiedzialność dyscyplinarną art. $119 \S 1$ k.k.w.

15 Z. Bugajski proponował wszystkie przewinienia więźniów pod względem dyscyplinarnym podzielić na 4 grupy: 1) zaniedbania i drobne przewinienia, 2) wykroczenia, 3) występki, 4) ciężkie występki, wskazując co się rozumie pod każdą kategorią przewinień i wskazując kary grożące za przewinienia przypisane do poszczególnych grup. Zob. Z. Bugajski, Zastosowanie w więziennictwie polskim progresywnego systemu odbywania kary, (w:) Z. Bugajski, E. Neymark, Aktualne zagadnienia i projekty reformy więziennictwa, Warszawa 1925, s. 323-331.

16 J. Śliwowski, Prawo polityka penitencjarna, op. cit., s. 203.

17 W rozporządzenie Ministra Sprawiedliwości z dnia 20 czerwca 1931 r. w sprawie regulaminu więziennego, (Dz.U. Nr 71, poz. 577) wyodrębniono cztery grupy przekroczeń, ale tylko w przypadku trzech grup wskazano w poszczególnych grupach odpowiednio czyny i kary, które za nie można wymierzyć (§ 166, § 167, § 168). W czwartej grupie (§ 167) nie wskazano konkretnych czynów, a jedynie zapisano, iż za przekroczenia regulaminowe nie wyszczególnione w $\S 166$ - $\S 168$ mają zastosowanie kary z katalogu kar.

Zob. R. Musidłowski, Karanie dyscyplinarne skazanych i tymczasowo aresztowanych (na przykładzie umieszczenia w celi izolacyjnej), (w:) Stan i węzłowe problemy polskiego więziennictwa. Cz. IV Wybrane instytucje kodeksu karnego wykonawczego w praktyce penitencjarnej, Biuletyn RPO, Materiały, Warszawa 2000, s. 303.

19 Ustawa z dnia 19 kwietnia 1969 r. Kodeks karny wykonawczy, Dz.U. z 1969 r. Nr 13, poz. 98 z późn. zm.

20 B. Stańdo-Kawecka, Prawne podstawy resocjalizacji, Kraków 2000, s. 160. 
wszystkich przekroczeń. Trafnie zauważa S. Pawela ${ }^{21}$, że pominięto chociażby zakaz popełniania przestępstw. Zaś T. Szymanowski ${ }^{22}$ zwraca uwagę, że „wśród różnych wymienionych w przepisach obowiązków (zakazów) skazany musi też wykonywać wszelkie polecenia przełożonych oraz innych uprawnionych osób, a różnorodność tych poleceń jest nie do określenia".

W tym miejscu rodzi się wątpliwość, czy Europejskie Reguły Więzienne zalecają przypisanie poszczególnym przekroczeniem określonych kar. Należy podzielić stanowisko R. Musidłowskiego ${ }^{23}$, reprezentowane na tle Europejskich Reguł Więziennych z 1987, iż z treści Reguł takie zalecenie nie wynika. Twórcy Reguł 2006 r. zalecają, jak już wskazano, określenie działania lub zaniechania więźnia, które stanowi naruszenie dyscyplinarne. Uczyniono to w art. $142 \S 1$ k.k.w. Zgodnie z tym przepisem skazany podlega odpowiedzialności dyscyplinarnej za zawinione naruszenie nakazów lub zakazów wynikających z ustawy, regulaminu lub innych przepisów wydanych na jej podstawie lub ustalonego w zakładzie karnym porządku. Wprawdzie jak zauważa S. Lelental ${ }^{24}$ przyjęcie, że poza źródłem nakazów i zakazów określonego zachowania się skazanego w zakładzie karnym lub poza nim są przepisy pozaustawowe oraz porządkowe osłabia funkcję gwarancyjną postępowania dyscyplinarnego, ale ma temu przeciwdziałać przepis art. $144 \S 3$ k.k.w. Z przywołanego przepisu wynika nakaz dokładnego określenia przekroczenia, co w ocenie cytowanego Autora oznacza, że „decyzja o ukaraniu musi zawierać kwalifikację prawną czynu tj. wskazywać przepis Kodeksu, regulaminu lub innego przepisu wydanego na podstawie ustawy lub ustalonego w zakładzie karnym porządku". Zważywszy na trudności w skatalogowaniu wszystkich przekroczeń rozwiązanie przyjęte w kodeksie karnym wykonawczym wydaje się najwłaściwsze i spełniające wymogi Europejskich Reguł Więziennych.

Zalecenie dotyczące kar dyscyplinarnych zostało spełnione. W kodeksie karnym wykonawczym umieszczono katalog kar dyscyplinarnych (art. $143 \S 1$ ). Katalog jest zamknięty. Kary usystematyzowano według abstrakcyjnego stopnia dolegliwości od kary najłagodniejszej do kary najdotkliwszej. Określono także maksymalny czas trwania kar dyscyplinarnych. Kary dyscyplinarne to:

- nagana,

- pozbawienie wszystkich lub niektórych niewykorzystanych przez skazanego nagród lub ulg albo zawieszenie ich wykonania, na okres do 3 miesięcy,

- pozbawienia korzystania z udziału w niektórych zajęciach kulturalno-oświatowych lub sportowych, z wyjątkiem korzystania z książek i prasy, na okres do 3 miesięcy,

T. Szymanowski, (w:) T. Szymanowski, J. Migdał, Prawo karne wykonawcze i polityka penitencjarna, Warszawa 2014, s. 373.

R. Musidłowski, Karanie dyscyplinarne skazanych i tymczasowo aresztowanych (na przykładzie umieszczenia w celi izolacyjnej), op. cit., s. 303.

S. Lelental, Kodeks karny wykonawczy. Komentarz, op. cit., s. 617. 
- pozbawienie możliwości otrzymywania paczek żywnościowych, na okres do 3 miesięcy,

- pozbawienie lub ograniczenie dokonywania zakupów żywnościowych lub wyrobów tytoniowych, na okres do 3 miesięcy,

- udzielanie widzeń w sposób uniemożliwiający bezpośredni kontakt z osobą odwiedzającą, na okres do 3 miesięcy,

- obniżenie przypadającej skazanemu części wynagrodzenia za pracę, nie więcej niż o $25 \%$, na okres do 3 miesięcy,

- umieszczenia w celi izolacyjnej na okres do 28 dni.

W porównaniu do katalogu kar w okresie obowiązywania kodeksu karnego wykonawczego z 1969 r. ${ }^{25}$ - a należy przypomnieć, iż wówczas tylko kary o najwyższym stopniu dolegliwości umieszczono w kodeksie karnym, zaś inne znalazły się $\mathrm{w}$ kolejnych regulaminach wykonywania kary pozbawienia wolności - istotnie zmniejszono, jak podkreślono w uzasadnieniu do projektu kodeksu karnego wykonawczego ${ }^{26}$, liczbę kar dyscyplinarnych. Proces eliminowania niektórych kar dyscyplinarnych rozpoczęty w $1974 \mathrm{r}^{27}$ następował systematycznie. I tak w $1981 \mathrm{r}^{28}$ zrezygnowano z kary dyscyplinarnej zmniejszenia racji żywnościowej i kary krótkiego ostrzyżenia włosów, a w 1990 r. ${ }^{29}$ wyeliminowano z katalogu kar w kodeksie karnym wykonawczym z 1969 r. karę twardego łoża w osobnej celi oraz karę umieszczenia w oddziale izolacyjnym na okres od miesiąca do 6 miesięcy. Tę karę zastąpiono karą osadzenia w celi izolacyjnej na okres do 1 miesiąca.

W kodeksie karnym wykonawczym z 1969 r. wskazano tylko cztery najsurowsze kary (art. 56 § 3). Były to: 1) obniżenie przysługujące skazanemu części wynagrodzenia za pracę, nie więcej niż o $25 \%$ na okres nie przekraczający 3 miesięcy; 2) pozbawienie lub ograniczenie widzeń na okres do 3 miesięcy; 3) twarde łoże w osobnej celi przez okres do $14 \mathrm{dni}$; 4) umieszczenie w celi izolacyjnej na okres od 1 do 6 miesięcy. W regulaminie wykonywania kary pozbawienia wolności z 1966 r. (zarządzenie Ministra Sprawiedliwości z dnia 7 lutego 1966 r. w sprawie regulaminu wykonywania kary pozbawienia wolności, Dz, Urz. MS nr 2, poz. 12) w katalogu kar było 15 kar. Poza wymienionymi w kodeksie karnym wykonawczym były to: 1) nagana na osobności, 2) nagana w obecności innych osób lub z podaniem do wiadomości, 3) pozbawienie wszystkich lub niektórych tylko nagród, 4) pozbawienie korzystania z udziału w niektórych zajęciach kulturalno-oświatowych przez okres do 3 miesięcy, 5) odbywanie spaceru w odosobnieniu przez okres do 3 miesięcy, 6) odbywanie widzeń przez siatkę przez okres do 3 miesięcy, 7) ograniczenie lub pozbawienie prawa korespondencji przez okres do 3 miesięcy, 8) pozbawienia prawa otrzymywania paczki, 9) ograniczenie lub pozbawienie prawa zakupu niektórych lub wszystkich artykułów żywnościowych przez okres do 3 miesięcy, 10) ograniczenie lub pozbawienie prawa zakupu niektórych lub wszystkich artykułów żywnościowych przez okres do 3 miesięcy oraz pozbawienie prawa paczki (§ 128).

26 Uzasadnienie rządowego projektu kodeksu karnego wykonawczego op. cit., s. 558.

27 W kolejnym regulaminie (zarządzenie Ministra Sprawiedliwości z dnia 25 stycznia 1974 r. w sprawie tymczasowego regulaminu wykonywania kary pozbawienia wolności, Dz. Urz. Min. Sprawiedliwości nr 2, poz. 6) w katalogu kar dyscyplinarnych wskazano 14 kar, zrezygnowano z kary odbywania widzeń przez siatkę, pozbawienia lub ograniczenia prawa do korespondencji prywatnej przez okres do 3 miesięcy, a także ograniczenia lub pozbawienia prawa zakupu niektórych lub wszystkich artykułów żywnościowych przez okres do 3 miesięcy oraz prawa otrzymania paczki. Wprowadzono zaś dwie nowe kary: jednorazowe krótkie ostrzyżenie włosów i zmniejszenie racji żywnościowej nie więcej niż o połowę przez okres do 14 dni.

28 Zarządzenie Ministra Sprawiedliwości z dnia 19 maja 1981 r. w sprawie zmiany tymczasowego regulaminu wykonywania kary pozbawienia wolności, Dz. Urz. Min. Sprawiedliwości nr 2, poz. 11.

29 Ustawa z dnia 23 lutego 1990 r. o zmianie Kodeksu karnego wykonawczego, Dz.U. z 1990 r. Nr 14, poz. 11. 
Eliminacja z katalogu kar dyscyplinarnych niektórych kar świadczyła o postępującym procesie humanizacji postępowania ze skazanymi w izolacji penitencjarnej i poszanowania godności ludzkiej skazanego.

Kolejne zalecenie Europejskich Reguł Więziennych, a mianowicie określenie $\mathrm{w}$ prawie krajowym procedur stosowanych $\mathrm{w}$ sprawach dyscyplinarnych należy uznać za zrealizowane przez ustawodawcę. Wymierzenie kary dyscyplinarnej poprzedza postępowanie wyjaśniające (art. $145 \S 2-5$ k.k.w.). W trakcie postępowania wysłuchuje się obwinionego, zapoznaje z opinią wychowawcy, a jeżeli zachodzi potrzeba również składającego wniosek o ukaranie, $z$ opiniami innych osób, a także z zeznaniami świadków zdarzenia.

W kodeksie karnym wykonawczym określono również dyrektywy wymiaru kar dyscyplinarnych (art. 145 § 1 k.k.w.). Do dyrektyw ogólnych doktryna ${ }^{30}$ zalicza stopień zawinienia i zasady indywidualizacji oraz cele wychowawcze, zaś do dyrektyw szczególnych zalicza się rodzaj i okoliczności czynu, stosunek do popełnionego przekroczenia, dotychczasową postawę sprawcy, cechy osobowości i stan zdrowia skazanego. Wskazane w przywołanym przepisie dyrektywy nie stanowią katalogu zamkniętego. Posłużenie się przez ustawodawcę sformułowaniem „w szczególności” dopuszcza uwzględnienie przez organ wymierzający karę dyscyplinarną także innych okoliczności.

Godzi się zwrócić uwagę na dodatkowe wymogi sformułowane przez ustawodawcę, a dotyczące wymierzenia niektórych kar dyscyplinarnych. Przed wymierzeniem kary umieszczenia w celi izolacyjnej niezbędna jest opinia lekarza albo psychologa o zdolności skazanego do odbycia tej kary. Także opinia lekarza, co do skutków dla zdrowia skazanego, jest konieczna przed wymierzeniem kary dyscyplinarnej pozbawienia możliwości otrzymania paczek żywnościowych na okres do 3 miesięcy i pozbawienia lub ograniczenia możliwości dokonywania zakupów artykułów żywnościowych lub wyrobów tytoniowych, na okres do 3 miesięcy, skazanemu, któremu ze względu na stan zdrowia zezwolono na dokonywanie dodatkowych zakupów artykułów żywnościowych lub otrzymywanie paczek o większym ciężarze albo korzystającemu $z$ diety.

Należy też wskazać na zakaz orzekania niektórych kar dyscyplinarnych wobec kobiet ciężarnych, karmiących lub sprawujących opiekę nad własnymi dziećmi w domach matki i dziecka. Te kary to: pozbawienia możliwości otrzymywania paczek żywnościowych, pozbawienia lub ograniczenia możliwości dokonywania zakupów artykułów żywnościowych oraz umieszczenia w celi izolacyjnej.

W kodeksie karnym wykonawczym spełniono kolejne zalecenie wynikające z Europejskich Reguł Więziennych, a mianowicie określenia organu upoważnionego do wymierzenia kary dyscyplinarnej. Kary dyscyplinarne, jak wynika z art. 144 
$\S 1$ k.k.w., wymierza dyrektor zakładu karnego lub osoba przez niego upoważniona. W przywołanym przepisie wskazano, które kary może wymierzyć osoba upoważniona. Są to: nagana, pozbawienie wszystkich lub niektórych nie wykorzystanych przez skazanego nagród lub ulg albo zawieszenie ich wykonania na okres do 3 miesięcy, pozbawienie korzystania z udziału w niektórych zajęciach kulturalno-oświatowych lub sportowych, $\mathrm{z}$ wyjątkiem korzystania $\mathrm{z}$ książek i prasy na okres do 3 miesięcy. Ustawodawca nie konkretyzuje, kogo może upoważnić dyrektor. Z regulaminu organizacyjno-porządkowego ${ }^{31}$ wynika, że w porządku wewnętrznym zakładu karnego dyrektor określa osoby upoważnione do wymierzania kar dyscyplinarnych. Zdaniem S. Lelentala ${ }^{32}$ upoważnienie może dotyczyć w szczególności podlegającego dyrektorowi funkcjonariusza kierującego wyodrębnionym oddziałem zakładu karnego. Wydaje się w pełni zasadnym podzielenie stanowiska ${ }^{33}$, iż dyrektor może upoważnić wychowawcę.

W Europejskich Regułach Więziennych sformułowano także zalecenia odnoszące się do uprawnień skazanego, któremu zarzucono popełnienie przekroczenia. Twórcy Reguł zwracają uwagę na niezwłoczne i szczegółowo poinformowanie skazanego o charakterze stawianych mu zarzutów i zapewnienie skazanemu czasu i środków dla przygotowania obrony. Nie mniej istotne jest zapewnienie skazanemu możliwości bronienia się osobiście lub korzystania z pomocy obrońcy oraz wnioskowania o stawienie się świadków oraz zadawania im pytań.

Analiza przepisów kodeksu karnego wykonawczego uzasadnia twierdzenie, że nasze regulacje wymagają udoskonalenia.

Skazany ma prawo do obrony materialnej, bowiem zgodnie z art. $145 \S 2$ k.k.w. przed wymierzeniem kary dyscyplinarnej wysłuchuje się skazanego, a więc może on złożyć wyjaśnienia czy przedstawić wnioski, np. co do wysłuchania świadków zdarzenia. Oczywiście może nie udzielać żadnych wyjaśnień, co nie powinno wpływać na ocenę jego czynu. Może korzystać z pomocy obrońcy, gdy ustanowił go w postępowaniu wykonawczym (art. 8 k.k.w.). Należy podzielić stanowisko, iż „niewielki udział obrońców w postępowaniu dyscyplinarnym otwiera drogę do szerszego wykorzystania instytucji przedstawiciela skazanego" ${ }^{\prime 34}$.

Problem powstaje w przypadku zalecenia dotyczącego umożliwienia skazanemu przygotowania się do obrony. Trudno wskazać na regulacje dotyczące tej kwestii. Wydaje się celowe zobowiązanie administracji zakładu karnego do przed-

31 Rozporządzenie Ministra Sprawiedliwości z dnia 25 sierpnia 2003 r. w sprawie regulaminu organizacyjno-porządkowego wykonywania kary pozbawienia wolności, Dz.U. z 2003 r. Nr 152, poz. 1493.

32 S. Lelental, Kodeks karny wykonawczy, op. cit., s. 621.

33 A. Kwieciński, Procedura wymiaru i wykonania kar dyscyplinarnych wobec skazanych na karę pozbawienia wolności Część I, op. cit., s. 212.

34 A. Kwieciński, Procedura wymiaru i wykonania kar dyscyplinarnych wobec skazanych na karę pozbawienia wolności Część l, op. cit., s. 215. 
stawiania skazanemu zarzutu na piśmie, co sugeruje także Komitet do spraw Zapobiegania Torturom ${ }^{35}$.

Kolejne z zaleceń twórców Europejskich Reguł Więziennych to wskazanie w prawie krajowym organu odwoławczego oraz procedury odwoławczej. W tej kwestii regulacje krajowe pozostają w pełnej zgodności z zaleceniami Reguł.

$\mathrm{Na}$ decyzję o ukaraniu dyscyplinarnym przysługuje skazanemu skarga do sądu z powodu jej niezgodności z prawem. W przypadku analizowanego postępowania taką decyzją będzie wymierzenie kary nie przewidzianej w katalogu kar dyscyplinarnych czy wymierzenie kary, gdy ustawodawca formułuje zakaz jej wymierzania w przypadku pewnej grupy skazanych, np. skazanej będącej w ciąży.

Skargę może złożyć obrońca, jeżeli skazany stanowił go w postępowaniu wykonawczym.

Zważywszy, iż na decyzję przysługuje skarga, decyzja musi spełniać warunki określone w art. $7 \S 3$ k.k.w. Należy zauważyć, iż ustawodawca sformułował dodatkowe warunki, jakie powinna spełniać decyzja o ukaraniu dyscyplinarnym (art. $144 \S 3$ i 4 k.k.w.). Przywołane przepisy zobowiązują podmiot wymierzający karę dyscyplinarną do sporządzenia decyzji o ukaraniu na piśmie, a także sporządzenia uzasadnienia decyzji. W decyzji należy określić przekroczenie popełnione przez skazanego. Ponadto decyzja powinna zawierać pouczenie o przysługującym skazanemu prawie, terminie i sposobie wniesienia skargi.

Godzi się zauważyć, iż ustawodawca nie tylko w gestii skazanego pozostawia instrument kontroli, ale także wskazuje na organy, które mają uprawnienie do kontroli decyzji dyrektora zakładu karnego, a więc także decyzji o ukaraniu dyscyplinarnym. Należy tu wskazać na sędziowski nadzór penitencjarny i kontrolę w ramach jednostek organizacyjnych Służby Więziennej.

Sprawowany przez sędziego penitencjarnego nadzór nad legalnością i prawidłowością wykonywania kary pozbawienia wolności obejmuje m.in. kontrolę i ocenę prawidłowego wymierzania kar dyscyplinarnych ${ }^{36}$. W ramach czynności nadzorczych sędzia penitencjarny uchyla sprzeczną z prawem decyzję dyrektora zakładu karnego (art. 34 § 1 k.k.w.). Zważywszy, iż z przywołanego przepisu - a właściwie zawartego w nim odesłania do art. 2 pkt 5 k.k.w. - wynika, że prawo uchylenia decyzji o ukaraniu dyscyplinarnym będzie dotyczyło tylko decyzji dyrektora zakładu karnego oraz osoby kierującej innym zakładem przewidzianym w przepisach prawa, powstaje pytanie co z decyzją o ukaraniu podjętą przez osobę upoważnioną przez dyrektora zakładu karnego. Wydaje się, że należy przyjąć, iż osoba upoważniona przez dyrektora nabywa w zakresie wymiaru kar dyscyplinarnych uprawnienia dyrektora i taka decyzja podlega kontroli sędziego penitencjarnego, a więc sędzia penitencjarny ją uchyla, gdy stwierdzi jej niezgodność z prawem. 
Należy zauważyć, że ustawodawca daje sędziemu penitencjarnemu dodatkowe kompetencje w zakresie kontroli wymierzania kar dyscyplinarnych. Te kompetencje to - zgodnie z art. 148 § 1 k.k.w. - prawo wstrzymania wykonania kary dyscyplinarnej na czas potrzebny do wyjaśnienia okoliczności uzasadniających jej wymierzenia, uchylenie kary dyscyplinarnej z powodu jej niezasadności, przekazanie sprawy dyrektorowi zakładu karnego do ponownego rozpoznania.

I tu powstaje problem. Zgodnie z art. $148 \S 1$ k.k.w. karę dyscyplinarną wykonuje się niezwłocznie. Zważywszy na przepis art. $147 \S 1$ k.k.w. - z którego wynika, że nie można rozpocząć wykonywania kary dyscyplinarnej po upływie 14 dni od jej wymierzenia - to tylko w tym okresie sędzia penitencjarny będzie mógł wykorzystać swoje ustawowe uprawnienia. Wszczęcie postępowania wyjaśniającego przez sędziego wstrzymuje bieg przedawnienia wykonania kary dyscyplinarnej. Nie określono jednak trybu, w jakim sędzia może wszcząć to postępowanie. Na dyrektorze zakładu karnego, jak zauważa S. Lelental ${ }^{37}$, nie ciąży obowiązek zawiadamiania sędziego penitencjarnego o wymierzeniu kary dyscyplinarnej. Należy więc podzielić ocenę przywołanego Autora, że uprawnienia sędziego penitencjarnego mogą okazać się iluzoryczne.

Inicjatywa zainteresowania sędziego decyzją o ukaraniu dyscyplinarnym pozostaje więc w gestii skazanego. Skazany ma prawo do złożenia skargi do sędziego penitencjarnego (art. 102 pkt 10 k.k.w.). W imieniu skazanego, może skargę złożyć ustanowiony na piśmie przez skazanego jego przedstawiciel. Upoważnienie dla skazanego do złożenia skargi do sędziego penitencjarnego wynika także z art. $33 \S 2$ k.k.w. Zgodnie z tym przepisem sędzia wizytując zakłady karne ma prawo przeprowadzać pod nieobecność innych osób rozmowy z osobami pozbawionymi wolności i badać ich skargi. Należy jednak zauważyć, iż zgodnie z rozporządzeniem w sprawie sposobu, zakresu i trybu sprawowania nadzoru penitencjarnego wizytacje okresowe przeprowadza się nie rzadziej niż raz w roku. Sędzia penitencjarny może także przeprowadzać wizytacje doraźne, ale jak można wnosić są przeprowadzane, gdy zaistnieją ku temu określone powody (np. skarga skazanego). Celowy więc wydaje się postulat informowania skazanego nie tylko o prawie złożenia skargi w trybie art. 7 k.k.w., ale też skargi do sędziego penitencjarnego, jak również do dyrektora okręgowego Służby Więziennej. Zgodnie bowiem z art. 78 § 2 - Dyrektor Generalny lub dyrektor okręgowy Służby Więziennej może uchylić decyzję dyrektora zakładu karnego sprzeczną z prawem ${ }^{38}$

Kolejne zalecenie dotyczy kary najbardziej dolegliwej z kar dyscyplinarnych - kary odosobnienia. Kara ta, w ocenie twórców Reguł, powinna być wymie-

37 S. Lelental, Kodeks karny wykonawczy. Komentarz (4 wyd.), s. 628-629.

$38 \quad$ Z badań Stowarzyszenia Interwencji Prawnej wynika, że skazani nie korzystają z prawa do odwołania się od decyzji o ukaraniu dyscyplinarnym obawiając się odwetu. Zob. M. Niełaczna, W. Klaus, Wykonywanie przez polskie władze zaleceń Europejskiego Komitetu do spraw Zapobiegania Torturom oraz Nieludzkiemu lub Poniżającemu Traktowaniu albo Karaniu (CPT). Raport z badań, (w:) Przestrzeganie praw osób pozbawionych wolności. O monitorowaniu jednostek penitencjarnych W. Klaus, M. Niełaczna (red.), Warszawa 2008, s. 187. 
rzana tylko w wyjątkowych przypadkach, na określony czas, tak krótki jak to tylko możliwe.

W katalogu kar jest kara dyscyplinarna umieszczenia w celi izolacyjnej. Kara ta nie tylko pozbawia skazanego kontaktu z innymi osobami, ale uniemożliwia korzystanie przez skazanego z szeregu praw oraz stwarza szereg dolegliwości w różnych sferach życia w zakładzie karnym ${ }^{39}$. Karę tę ustawodawca traktuje jako środek szczególny, bowiem dopuszcza jej wymierzenie tylko w przypadku popełnienia przez skazanego przekroczenia naruszającego w poważnym stopniu obowiązującą w zakładzie karnym dyscyplinę i porządek ${ }^{40}$. Ponadto niezbędna jest opinia lekarza lub psychologa o zdolności skazanego do odbycia tej kary. Zaś w czasie jej wykonywania psycholog lub lekarz kontroluje zdolność skazanego do jej odbywania. Gdy stan zdrowia uniemożliwia odbywanie tej kary, a także każdej innej, po zasięgnięciu opinii lekarza dyrektor zakładu karnego wykonanie kary może przerwać albo zamienić karę na inną, którą skazany może odbywać. Wprawdzie maksymalny czas trwania kary dyscyplinarnej umieszczenia w celi izolacyjnej określono na 28 dni, to gdy dyrektor zakładu karnego zdecyduje się wymierzyć tę karę na okres powyżej 14 dni, niezbędna jest zgoda sędziego penitencjarnego. Jest to więc pewien element kontroli celowości orzekania tej kary.

Twórcy Reguł uznają za niedopuszczalną karę zawierającą całkowity zakaz kontaktów z rodziną. Wprawdzie w katalogu kar nie ma takiej kary, jednak kara celi izolacyjnej istotnie ogranicza kontakt skazanego z rodziną, bowiem pozbawia się skazanego korzystania z widzeń i samoinkasujących aparatów telefonicznych, a więc jedyna forma kontaktu to korespondencja. Należy jednak zauważyć, iż dyrektor zakładu karnego może w wypadkach uzasadnionych względami rodzinnymi, osobistymi lub wychowawczymi, zezwolić skazanemu na widzenie lub rozmowę telefoniczną.

Analiza przepisów kodeksu karnego wykonawczego dotyczących postępowania dyscyplinarnego pozwala na stwierdzenie, że zalecenia wynikające z Europejskich Reguł Więziennych - zarówno w wersji z 1987 r., jak i 2006 r. - zostały przez ustawodawcę uwzględnione. Tę ocenę uzasadnia także fakt, iż podczas wizytacji $\mathrm{CPT}^{41}$

Szerzej zob. G.B. Szczygieł, Kara dyscyplinarna umieszczenia w celi izolacyjnej a standardy op. cit., s. 260 i n. Z praktyki wynika, iż tę karę najczęściej wymierza się w przypadku: posiadania przez skazanego środków psychotropowych, odmowy poddania się testom na obecność narkotyków we krwi, bójki w celi między współwiężniami, agresji wobec funkcjonariusza, niszczenia mienia. Zob. szerzej M. Niełaczna, W. Klaus, Wykonywanie przez polskie władze zaleceń Europejskiego Komitetu do spraw Zapobiegania Torturom oraz Nieludzkiemu lub Poniżającemu Traktowaniu albo Karaniu, op. cit., s. 187.

Zob. Sprawozdanie przyjęte 4 grudnia 1966 r. dla polskiego rządu na temat wizyty od 30 czerwca do 12 lipca 1996 r. w Polsce przeprowadzonej przez Europejski komitet ds. zapobiegania Torturom i Nieludzkiemu lub Poniżającemu Traktowaniu lub Karaniu (CPT), „Przegląd Więziennictwa Polskiego” 1999, nr 24-25, s. 116-149; Sprawozdanie dla polskiego rządu z wizyty w Polsce przeprowadzonej przez Europejski Komitet ds. Zapobiegania Torturom lub Poniżającemu Traktowaniu lub Karaniu (CPT) 8-9 maja 200 r., „Przegląd Więziennictwa Polskiego 2002", nr 36, s. 127-155; Sprawozdanie dla Polskiego Rządu z wizyty Europejskiego Komitetu ds. Zapobiegania Torturom i Nieludzkiemu oraz Poniżającemu Traktowaniu lub karaniu (CPT) w dniach od 4 do 15 października 2004 r., „Przegląd Więziennictwa Polskiego” 2006, nr 50, s. 149-184; Report to the Polish Government on the visit to Poland carried out by the European Committe for the Prevention of Torture an Inhuman or Degrading tre- 
w polskich zakładach karnych, a odbyły się cztery wizytacje, przedstawiciele CPT nie zgłaszali żadnych zastrzeżeń zarówno co do przepisów odnoszących się do postępowania dyscyplinarnego i sankcji, jak i praktyki wymierzania i wykonywania kar dyscyplinarnych. Takie instytucje, jak odstąpienie od wymierzenia kary, zawieszenie wykonania kary czy darowania świadczą o respektowaniu zasady humanitaryzmu w postępowaniu dyscyplinarnym. 


\section{DISCIPLINARY PROCEDURES IN THE PENAL EXECUTIVE CODE IN THE LIGHT OF THE 2006 EUROPEAN PRISON RULES}

In their work, the authors of the 1997 Penal Executive Code used a number of international documents as a reference. The list of treaties ratified by Poland, such as the European Convention for the Protection of Human Rights and Fundamental Freedoms and the International Covenant on Civil and Political Rights, included the European Prison Rules which Poland, as a member of the Council of Europe, is obliged to observe. At the time of the work on the Penal Executive Code, the applicable model rules were the European Prison Rules of 1987. In 2006, a new version of the European Prison Rules was adopted. This creates grounds for an analysis of the provisions of the Code that pertain to the procedures implemented in relation to convicts from the point of view of the guidelines provided for in the Prison Rules. Given the broad scope of the provisions, the present article focuses on disciplinary proceedings. The objective of the article is to answer the question of whether the provisions of the Penal Executive Code comply with the recommendations defined in the European Prison Rules. The discussion contained herein focuses on the most important recommendations, namely the ultima ratio principle of disciplinary proceedings, the definiteness of the inmates' behavior that constitutes a violation and the penalties it carries, the definiteness of the disciplinary procedures, the body authorized to impose penalties, and the appeal body and procedure, as well as the rights of inmates that were accused of committing a violation.

Keywords: penalty of imprisonment, convict, disciplinary proceeding, disciplinary penalty 